\title{
Stable isotopes prove shell growth bands in the Antarctic bivalve Laternula elliptica to be formed annually
}

Received: 16 July 1995 / Accepted: 27 October 1996

\begin{abstract}
Growth marks in calcareous shells or skeleton parts of benthic invertebrates are often assumed to be formed annually and hence are used for ageing purposes. For some Antarctic species this assumption has been validated by tagging experiments or direct monitoring of growth throughout the year. Here we use the record of stable isotope ratios $\left(\delta^{18} \mathrm{O}\right.$ and $\left.\delta^{13} \mathrm{C}\right)$ deposited in shell carbonate of Laternula elliptica from King George Island to demonstrate that shell growth bands are formed annually in this species.
\end{abstract}

\section{Introduction}

Individual age is a key parameter of population dynamics. Age is required to establish growth and mortality patterns from which productivity of the population can be derived. Among those benthic organisms with calcareous shells or skeleton parts (e.g. corals, bryozoans, molluscs or echinoderms), many species exhibit growth band patterns. These bands are produced by alternate deposition of skeleton material of different density or structure. The alternation is triggered either by changes in environmental factors, such as temperature, salinity, oxygen or food supply or by internal factors such as reproduction (see e.g. Merrill et al. 1965; Thompson et al. 1980; Ebert 1988). These events may be part of a regularly repeated annual cycle, but they may also occur irregularly and non-predictably. Hence the growth band pattern itself neither tells us if the bands observed are formed at regular intervals in time nor how many bands are formed per year.

AWI Publication No. 1146

T. Brey $(\bowtie) \cdot$ A. Mackensen

Alfred Wegener Institute for Polar and Marine Research,

Postfach 120 161,

D-27515 Bremerhaven, Germany

e-mail: tbrey@awi-bremerhaven.de
Therefore an assumed annual growth band formation has to be validated by an independent approach.

Hitherto in the Antarctic, growth band formation has been validated in three benthic species either by tagging-recapture experiments or by year-round monitoring of growth: the bryozoan Cellarinella watersi (Barnes 1995), the bivalve Yoldia eightsi (Nolan and Clarke 1993; Peck and Bullough 1993), and the echinoid Sterechinus antarcticus (Brey et al. 1995) were proved to deposit growth bands annually. The growth marks in the shell of the brachiopod Liothyrella uva, however, were found to be formed at a rate of about one band per 1.8 years (Peck and Brey 1996).

Laternula elliptica (King and Broderip), a large (maximum length $>100 \mathrm{~mm}$ ) and deep-burrowing bivalve, is widespread on muddy sediments around the Antarctic continent (Powell 1965). At some sites at the Antarctic islands (e.g. King George Island, Signy Island) it is a dominant species in terms of abundance and biomass (Everson and White 1969; Hardy 1972; Urban and Mercuri in press). The bivalve shows a distinct pattern of growth bands visible on the shell surface and in sections of the chondrophore that have been used for ageing purposes by Ralph and Maxwell (1977) and Urban and Mercuri (in press).

The ratio of the oxygen isotopes ${ }^{18} \mathrm{O}$ and ${ }^{16} \mathrm{O}\left(\delta^{18} \mathrm{O}\right)$ in mollusc shell carbonate depends on seawater isotope composition and temperature during shell deposition. Deep ocean seawater isotope composition is stable on a biological time scale, and hence calcitic shell $\delta^{18} \mathrm{O}$ can be related to ambient temperature via the paleotemperature equations of Epstein et al. (1953) and McCrea (1950). The ratio of the carbon isotopes ${ }^{13} \mathrm{C}$ and ${ }^{12} \mathrm{C}$ in shell carbonate is less temperature affected (Emrich et al. 1970), but depends mainly on changes in $\delta^{13} \mathrm{C}$ of seawater bicarbonate mediated by primary production (Krantz et al. 1987). These relations can be used to derive environmental and ecological information from living or fossil calcareous species (see Krantz et al. 1987; Wefer and Berger 1991). 
Following the previous attempts of Jones et al. (1983), Krantz et al. (1984), Donner and Nord (1986) and others, we used oxygen and carbon isotope profiles in the shell to test whether or not growth bands are formed annually in Laternula elliptica. Because $\delta^{18} \mathrm{O}$ of water is inversely related to temperature and $\delta^{13} \mathrm{C}$ of dissolved inorganic carbon in pore and bottom waters is reduced during, or shortly after, periods of high primary production, we expected to find lower values in those parts of the shell deposited during spring/ summer and higher values in shell material formed in autumn/winter.

\section{Materials and methods}

Specimens of Laternula elliptica were sampled at Potter Cove, a small inlet adjacent to Maxwell Bay, King George Island, Antarctica $\left(62^{\circ} 14^{\prime} \mathrm{S}, 58^{\circ} 40^{\prime} \mathrm{W}\right)$ by scuba diving in $25-\mathrm{m}$ water depth. Temperature in $25-\mathrm{m}$ water depth ranges between $+1^{\circ} \mathrm{C}$ in February and $<-1.2^{\circ} \mathrm{C}$ in November (Klöser et al. 1993), but is likely to decrease to $-1.8^{\circ} \mathrm{C}$ during July/August, as observed at Signy Island (Clarke et al. 1988). Despite the glacier input in the cove, salinity remains between $34.0 \mathrm{ppt}$ and $34.2 \mathrm{ppt}$ in $25-\mathrm{m}$ water depth (Klöser et al. 1993). There are no primary production data available from Potter Cove, but data from Admiralty Bay indicate a sharp peak of production in January/February (Domanov and Lipski 1990).

We selected several large (approx. $100 \mathrm{~mm}$ length) specimens from the samples, removed the soft parts and cleaned the shells with warm $5 \% \mathrm{NaOCl}$. After subsequent washing with $90 \%$ ethanol and drying, the shell surface was slightly ground. The shell of Laternula elliptica consists of two layers of which the outer one is very thin and fragile. On all valves examined parts of the outer layer were lost, mainly in the dorsal region. We selected the most intact valve (103 mm length, $63 \mathrm{~mm}$ height) for further analysis. Growth bands were counted at the shell surface and on a crosssection of the chondrophore. For isotope analysis, 43 carbonate samples of ca. $50 \mu \mathrm{g}$ each were drilled from the outer shell layer in an equally spaced dorsal-to-ventral series using a small dental drill (bit size $0.5 \mathrm{~mm}$ ).

Stable oxygen and carbon isotopes of the carbonate samples were measured with a Finnigan MAT251 mass spectrometer coupled to an automatic carbonate preparation device. Standard deviations of measurements are $<0.04 \%$ and $<0.06 \%$ for carbon and oxygen, respectively. Data are related to the Pee Dee belemnite (PDB) standard through repeated analyses of $\mathrm{Na}-$ tional Bureau of Standard isotopic reference material (NBS) 19 (Hut 1987).

\section{Results}

The shell surface of Laternula elliptica shows a ripple structure where wider crests alternate with narrower troughs. Occasionally a secondary pattern of fine parallel lines makes this structure difficult to detect, especially in the younger part of the shell. On the shell surface of the 1 valve selected for analysis we were able to identify 16 crests separated by 15 troughs. The examination of the chondrophore cross-section revealed a total of 21 wide bands corresponding to shell surface crests, i.e. 5 of these bands could not be identified clearly on the shell surface.
From the 43 carbonate samples, 1 (no. 11) was omitted from further analysis due to an insufficient amount of carbonate collected and 1 (No. 43) was omitted because it was contaminated with carbonate from the inner shell layer. Visual inspection of the shell showed 17 samples to be situated on a crest and 16 to be situated in a trough, whereas 7 samples could not be classified clearly. Both $\delta^{18} \mathrm{O}$ and $\delta^{13} \mathrm{C}$ values of crest samples were significantly lower than those of trough samples $\left(\delta^{18} \mathrm{O}\right.$ mean: 2.758 vs. $3.143, P<0.001 ; \delta^{13} \mathrm{C}$ mean: 0.705 vs $1.125, P=0.037$ ), indicating that crests are deposited during spring/summer and troughs during autumn/winter. Figure 1 shows the complete $\delta^{18} \mathrm{O}$ and $\delta^{13} \mathrm{C}$ profiles.

\section{Discussion}

Our sample series (Fig. 1) does not show the clear picture of $\delta^{18} \mathrm{O}$ and $\delta^{13} \mathrm{C}$ profiles derived from other bivalve species, where a distinct wave pattern of rising and falling isotope values was observed (Placopecten magellanicus, Krantz et al. 1984; Spisula solidissima, Arthur et al. 1983, Jones et al. 1983; mytilide mussels, Donner and Nord 1986, Margosian et al. 1987). Moreover, the average difference in $\delta^{18} \mathrm{O}$ measured be-

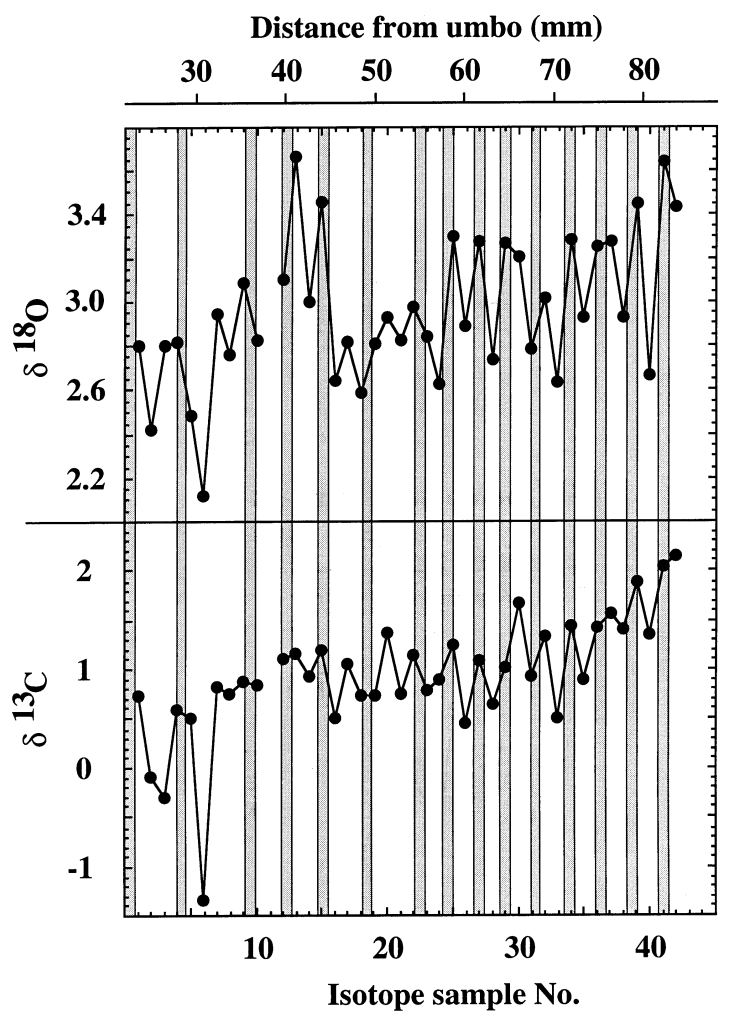

Fig. $1 \delta^{18} \mathrm{O}$ and $\delta^{13} \mathrm{C}$ profiles along a dorsal-to-ventral transect in the outer shell layer of $L$. elliptica. Distance from umbo measured along the shell surface. Total distance from umbo to shell edge is 85.4 $\mathrm{mm}$. Grey bars indicate positions of clearly identifiable winter growth bands (troughs) 
tween crests and troughs is $60 \%$ lower than expected from a temperature difference of $2.8^{\circ} \mathrm{C}$. This may be related to methodological shortcomings: compared to the species mentioned above, Laternula elliptica grows slowly and the distance between adjacent summer and winter growth bands is small. Obviously the resolution of our carbonate sample series is too coarse, and more, but smaller and closer spaced, samples would be required to achieve a clear separation of summer and winter growth bands and a better resolution comparable to the above examples. However, the statistical comparison of crest and trough data is still possible, and both the $\delta^{18} \mathrm{O}$ and $\delta^{13} \mathrm{C}$ data confirm that the shell growth bands of Laternula elliptica are annual markers: the crests are deposited during spring/summer and troughs are deposited during autumn/winter (Fig. 1). Hence, these growth bands can be used for age determination; however, the corresponding internal bands of the chondrophore provide a more reliable age estimate than the shell surface bands.

In contrast to the $\delta^{18} \mathrm{O}$ record, there seems to be an overall trend of increasing $\delta^{13} \mathrm{C}$ values with increasing size of the mollusc (Fig. 1), which may be caused by ontogenetic or environmental changes.

Ontogenetic trends in $\delta^{13} \mathrm{C}$ have been observed in several mollusc species (see Krantz et al. 1987; Wefer and Berger 1991). They are assumed to be related to changes in metabolic activity such as maturation, which are known to affect the $\delta^{13} \mathrm{C}$ record. However, in most examples presented in the literature, the general trend is towards lighter values during life. Only Tridacna maxima shows an ontogenetic shift towards heavier $\delta^{13} \mathrm{C}$ similar to that seen in Laternula elliptica.

It is also possible that ventilation changes of bottom and pore waters occurred within the last 25 years, or a gradual change in phytoplankton species composition resulted in a different $\delta^{13} \mathrm{C}_{\mathrm{SCO}_{2}}$ composition of bottom waters. It might even be possible that a local change in bottom current velocity or direction caused a shift in the composition of organic detritus on the sea-floor. So a

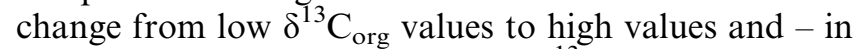
turn - less depleted bottom water $\delta^{13} \mathrm{C}_{\Sigma \mathrm{CO}_{2}}$ values, and consequently higher $\delta^{13} \mathrm{C}$ values in the bivalve shell may have occurred.

Seasonal changes in growth rate have been observed in many Antarctic species; however, it still remains unclear whether temperature or food supply is the main factor controlling growth (Clarke 1988; Brey and Clarke 1993; Nolan and Clarke 1993). Seasonal variability in food supply seems to be the more prominent environmental cycle (e.g. Clarke 1988; Matsuda et al. 1990; Wefer and Fischer 1991), because the annual temperature range (about $2.8^{\circ} \mathrm{C}$ in shallow waters around the Antarctic islands, less than $1^{\circ} \mathrm{C}$ at highAntarctic sites) is very small compared to boreal areas. However, growth of calcareous shells may be decoupled from body growth, as observed in the brachiopod Liothyrella uva, which shows the highest shell growth rates during winter (Peck et al. in press) and no annual growth band formation (Peck and Brey 1996). Stable isotope ratios may help in the analysis of such difficult growth patterns in Antarctic benthic invertebrates.

Acknowledgements We wish to thank Kerstin Beyer, who prepared the shell carbonate samples, and Gaby Traue, as well as Günter Meyer, who carried out the isotope measurements. The first author's dentist, Dr. G. Hoops, provided the drills used for collecting carbonate powder from the bivalve shell.

\section{References}

Arthur MA, Williams DF, Jones DS (1983) Seasonal temperaturesalinity changes and temocline development in the mid-Atlantic Bight as recorded by the isotopic composition of bivalves. Geology 11:655-659

Barnes DKA (1995) Seasonal and annual growth in erect species of Antarctic bryozoans. J Exp Mar Biol Ecol 188:181-198

Brey T, Clarke A (1993) Population dynamics of marine benthic invertebrates in Antarctic and subantarctic environments: are there unique adaptations? Antarct Sci. 5:253-266

Brey T, Pearse J, Basch L, McClintock J, Slattery M (1995) Growth and production of Sterechinus neumayeri (Echinoidea, Echinodermata) in McMurdo Sound, Antarctica. Mar Biol 124:279-292

Clarke A (1988) Seasonality in the Antarctic marine environment. Comp Biochem Physiol 90B:461-473

Clarke A, Holmes LJ, White MG (1988) The annual cycle of temperature, chlorolphyll and major nutrients at Signy Island, South Orkney Islands, 1969-82. Br Antarct Surv Bull 80:6586

Domanov MM, Lipski M (1990) Annual cycle of chlorophyll $a$ and primary production of phytoplankton in Admiralty Bay (Antarctica). Pol Arch Hydrobiol 37:471-478

Donner J, Nord AG (1986) Carbon and oxygen stable isotope values in shells of Mytilus edulis and Modiolus from holocene raised beaches at the outer coast of the Varanger Peninsula, north Norway. Palaeogeogr Palaeoclimatol Palaeoecol 56:3550

Ebert TA (1988) Calibration of natural growth lines in ossicles of two sea urchins, Strongylocentrotus purpuratus and Echinometra mathaei, using Tetreacycline. In: Burke RD, Mladenov PV, Lambert P, Parsley RL (eds) Echinoderm biology. Balkema, Rotterdam, pp 434444

Emrich K, Erhalt DH, Vogel JC (1970) Carbon isotope fractionation during the precipitation of calcium carbonate. Each Planet Sci Lett 8:363-371

Epstein S, Buchsbaum R, Lowenstam HA, Urey HC (1953) Revised carbonate-water isotopic temperature scale. Bull Geol Soc Am 64:1314-1325

Everson I, White MG (1969) Antarctic marine biological research methods involving diving. Underwater Assoc Rep 4:91-95

Hardy P (1972) Biomass estimates for some shallow-water infaunal communities at Signy Island, South Orkney Islands. Br Antarct Surv Bull 31:93-106

Hut G (1987) Consultant's group meeting on stable isotope reference samples for geochemical and hydrological investigations. Report to the Director General. International Atomic Energy Agency. Vienna, 44

Jones DS, Williams DF, Arthur MA (1983) Growth history and ecology of the Atlantic surf clam, Spisula solidissima (Dillwyn), as revealed by stable isotope and annual shell increments. J Exp Mar Biol Ecol 73:225-242

Klöser H, Ferreyra G, Schloss I, Mercuri G, Laturnus F, Curtosi A (1993) Seasonal variation of algal growth conditions in sheltered Antarctic bays: the example of Potter Cove (King George Island, South Shetlands). J Mar Systems 4:289-301

Krantz DE, Jones DS, Williams DF (1984) Growth rates of the sea scallop, Placopecten magellanicus, determined from the 180/160 record in shell calcite. Biol Bull Woods Hole Mass 167:186-199 
Krantz DE, Williams FD, Jones DS (1987) Ecological and paleoenvironmental information using stable isotope profiles from living and fossil molluscs. Palaeogeogr Palaeoclimatol Palaeoecol 58:249-266

Margosian A, Tan FC, Cai D, Mann KH (1987) Seawater temperature records from stable isotope profiles in the shell of Modiolus modiolus. Estuarine Coastal Shelf Sci 25:81-89

Matsuda, O, Ishikawa, S, Kawaguchi, K (1990) Seasonal variation of particulate organic matter under the Antarctic fast ice and its importance to benthic life. In: Kerry KR, Hempel G (eds) Antarctic ecosystems. Ecological change and conservation. Springer, Berlin Heidelberg New York, pp 143-148

McCrea JM (1950) On the isotopic chemistry of carbonates and a paleotemperature scale. J Chem Phys 18:849-857

Merrill AS, Posgay JA, Nichy FE (1965) Annual marks on the shell and ligament of the sea scallop (Placopecten magellanicus). Fish Bull 65:299-311

Nolan CP, Clarke A (1993) Growth in the bivalve Yoldia eightsi at Signy Island, Antarctica, determined from internal shell increments and calcium-45 incorporation. Mar Biol 117:243-250

Peck LS, Brey T (1996) Bomb signals from old Antarctic brachiopods. Nature 380:207-208

Pecks LS, Bullough LW (1993) Growth and population structure in the infaunal bivalve Yoldia eightsi in relation to ice- berg activity at Signy Island, Antarctica. Mar Biol 117:235241

Peck LS, Brockington S, Brey T (in press) Growth and metabolism in the Antarctic brachiopod Liothyrella uva. Antarct Sci

Powell AWB (1965) Mollusca of Antarctic and subantarctic seas. In: van Oye P, van Mieghem J (eds) Biogeography and ecology in Antarctica. Junk, The Hague, pp 330-380

Ralph R, Maxwell GH (1977) The oxygen consumption of the Antarctic limpet Nacella (Patinigera) concinna. Br Antarct Surv Bull 45:19-23

Thompson I, Jones DS, Dreibelbs D (1980) Annual internal growth banding and life history of the ocean ouahog Arctica islandica (Mollusca: Bivalvia). Mar Biol 57:25-34

Urban HJ, Mercuri G (in press) On the population dynamics of the bivalve Laternula elliptica from Potter Cove (King George Island, Antarctic Peninsula): influence of water currents explaining the occurrence of two sub-populations. Mar Biol

Wefer G, Berger WH (1991) Isotope paleontology: growth and composition of extant calcareous species. Mar Geol 100:207248

Wefer G, Fischer G (1991) Annual primary production and export flux in the southern ocean from sediment trap data. Mar Chem 35:597-613 